\title{
Sociology of ritual and narrative as post- Western sociology: from the perspective of Confucianism and Nativism in the Edo period of Japan
}

Yoshiyuki Yama

Correspondence: bel12665@ kwansei.ac.jp

School of Human Welfare Studies, Department of Holistic Human Sciences, Kwansei Gakuin University, 1-155 Uegahara 1bancho, Nishinomiya, Hyogo 662-8501, Japan

\begin{abstract}
Modern sciences were introduced to Japan from Western countries during the Meiji period. In other words, this was the process of translating Western academic languages into Japanese academic languages. The translation was meant to reuse existing Chinese characters with similar meanings to Western academic languages or create new Chinese characters. Japan was able to rapidly introduce modern Western science during the Meiji period because it already had academic languages comparable to modern Western science; thus, the translation proceeded smoothly. This means that academic ways of thinking that were comparable to modern Western science were developing in Japan. At that time, modern Japanese society first encountered sociology as modern science. Sociology was translated into the Chinese characters "社会学 (Syakaigaku)" and introduced to Japan. The term Syakaigaku first appeared in Japan during the Meiji period; however, before that, early modern Japan had developed several kinds of sociological thought. The purpose of this paper is to examine the history of Japanese thought, especially the new types of Confucianism and Nativism (Kokugaku), in the Edo period in comparison with Western sociology. Various remarkable thoughts similar to those seen in Western sociology are found. This paper then reviews a Nativism scholar, Motoori Norinaga, who was active during the Edo period and influenced Japanese environmental sociology through the folklorist Kunuo Yanagita. Finally, a new sociology, which combines the Western sociological theory of ritual, the Japanese Confucian theory of ritual by Ogyu Sorai, and the narrative theory of Norinaga, is presented.
\end{abstract}

Keywords: Confucianism, Nativism (Kokugaku), Sociology of ritual and narrative

\section{Introduction}

Starting in the Meiji period, Japan was introduced to many studies from modern Western Europe. In other words, this was the process of translating Western academic languages into Japanese academic languages. The translation was meant to reuse existing Chinese characters that had similar meanings to Western academic languages or create

(c) The Author(s). 2021 Open Access This article is licensed under a Creative Commons Attribution 4.0 International License, which permits use, sharing, adaptation, distribution and reproduction in any medium or format, as long as you give appropriate credit to the original author(s) and the source, provide a link to the Creative Commons licence, and indicate if changes were made. The images or other third party material in this article are included in the article's Creative Commons licence, unless indicated otherwise in a credit line to the material. If material is not included in the article's Creative Commons licence and your intended use is not permitted by statutory regulation or exceeds the permitted use, you will need to obtain permission directly from the copyright holder. To view a copy of this licence, visit http://creativecommons.org/licenses/by/4.0/. 
new Chinese characters. Japan was rapidly introduced to modern Western science during the Meiji period because it already had academic languages comparable to modern Western science; thus, the translation proceeded smoothly. This means that academic ways of thinking that were comparable to modern Western science were developing in Japan.

At that time, modern Japanese society first encountered sociology as modern science. Sociology was translated into the Chinese characters “社会学 (Syakaigaku)" and introduced to Japan. In the beginning, the Chinese characters “世態学 (Setaigaku)” were also used, but this term eventually became accepted as “社会学.” However, sociological thought existed in premodern Japan as well. Though there was no term for sociology, thoughts comparable to those found in sociology in modern Western Europe were developing in Japan during the Edo period.

The international situation in East Asia changed significantly following the transition of the Chinese dynasty from Han Chinese to Manchu, which was known as the MingQing transition (明清交替). The status of the Chinese Empire changed, and in the neighboring country of Korea, the Joseon Dynasty implemented "Sojunghwaism (小中 華主義)," which situated the country as an orthodox successor to Chinese civilization. Similarly, in Japan, a new Confucianism called "Kogaku (古学)" appeared, which criticized the interpretations of Edo Neo-Confucianism and attempted a direct philological and linguistic approach to Chinese classics. Among them, an original Japanese study of Nativism (Kokugaku, 国学), a philological and linguistic approach to Japanese classics and Chinese classics, emerged. In other words, Kogaku and Japanese Nativism were born in the period of post-Confucianism (Yama 2019).

Since Masao Maruyama (1914-1996), a leading political scientist in Japan, recognized the beginning of modern thinking as a process of development from Kogaku to Nativism “日本政治思想史研究”1 (Maruyama 1952), Kogaku and Nativism have become the most significant subjects of study in the history of Japanese thought. In particular, Maruyama recognized the political thinking of Ogyu Sorai (荻生徂徠, 1666-1728) as being comparable to that of modern Western Europe. Likewise, this paper intends to argue that a type of sociological thinking is recognizable in Kogaku and Nativism.

This paper introduces the sociology of rituals and narratives, which adopts the ritualism of Confucian philosopher Ogyu Sorai and the narrative theory of Nativism scholar Motoori Norinaga (本居宣長, 1730-1801), to Western sociology theory.

The translation is a creative work. Translating Western academic languages into theoretical academic languages is also a process of creating disciplines with new hybrid ways of thinking. Japanese scholars during the Meiji period worked to create hybrid studies deliberately. This paper is also such a translation attempt.

\section{Sociology of ritual}

\section{Symbolic recovery}

In the past, the reconstruction and recovery of disaster-affected communities progressed in the direction of the review and redevelopment of urban planning by mobilizing knowledge and skills from natural science perspectives, especially civil engineering. Thus, as long as the concept of recovery was based on civil engineering knowledge and

${ }^{1}$ It was published in 1974 in English, titled "Studies in the Intellectual History of Tokugawa Japan." 
skills, the contents of recovery also resulted in making something better from a civil engineering perspective. However, it is empirically known that the recovery of disasteraffected communities requires considering not only physical infrastructures but also culture and psychological feelings. If the community members cannot feel that "we have recovered," then recovery has not been achieved, even if it is regarded as being recovered by objective criteria, including a civil engineering perspective. Recovery is realized at the level of people's symbolic semantic systems.

If recovery is ritually directed and realized at the symbolic semantic system level, it is considered effective in recovering cultural heritage and festivals, which are symbols of local communities.

Disaster-affected communities have collective traumatic memories. The restoration of local symbols represents a recovery of the community's feelings. What is interesting about this phenomenon is that the recovery of symbols leads to infrastructure recovery.

The author of this paper has suggested the concept of recovery as "symbolic recovery" based on such thinking, distinguished from the conventional concept of civil engineering recovery. Moreover, theoretical reviews have been conducted based on the ritualism, symbolism, and community theory of anthropologists and sociologists, including Emile Durkheim (1912), Arnold van Gennep (1909), Clifford Geertz (1980), Benedict Anderson (1991), Anthony Cohen (1985), Claude LéviStrauss (1958), Mary Douglas (1970), and Victor Turner (1969). However, what is important is that our argument introduces a perspective that is not in their anthropological and sociological ritualism. It is the perspective that people "produce" rituals that create recovery at the symbolic level to gain a feeling of recovery.

Administrators responsible for completing recovery, including recovery planners and heads of local governments, recognize that recovery is formed ritualistically and give shape to and express the sense of recovery created among people, not just civil engineering criteria. In other words, it points out the importance of intentionally designing and properly implementing the recovery ritual to create recovery (Yama 2006).

\section{Shift to production theory}

A barrier to arguing the "production view of ritual" was the traditional ritualism framework in sociology and anthropology. It is because of this way of thinking that administrators, including recovery planners and heads of local governments, are not suitable for conventional ritualism; this is in spite of the fact that the people in such positions are responsible for recovery and are given autonomy in regard to deciding and implementing measures independently of the social group. In conventional ritualism, it is thought that a specific individual also belongs to a social group. An individual's consciousness reflects the social group's unconsciousness; thus, the individual's intention represents the social group's intention. This could be called a "social reductionist way of thinking." Such a process is inevitable as long as the logic of interpreting the situation related to society is observed after watching the progress of the situation to the end.

However, there will be differences between a specific individual's consciousness and a social group's unconsciousness. Even if it is not one specific individual driving the intentions, there will be substantial differences between the individual's intention and the 
social group's intention to which the individual belongs. Even a small community would reflect the same differences. Researchers seem to feel that they can isolate the social group's intention by excluding these differences.

Within a social group, a person who belongs to the group but has a perspective that seems to look at the group from the outside is well aware of the situation inside the group and plays a role in the group's operation. At the same time, the person can learn external knowledge and skills, obtain external information, and build external networks, thereby changing the situation inside the group while using knowledge, skills, information, and human networks from the outside. The author has named those types of people the "intermediate intellectual." It is thought that these intermediate intellectuals cause actions and that these actions act on the social group and react to the social group, thereby changing the situation gradually by repeating the interactions like the two focal points of the ellipse (Yama 2020). It is also thought that these intermediate intellectuals are involved in designing and implementing recovery rituals. These changes of viewpoint on rituals result in a "production theory."

The ritualism theory of Ogyu Sorai, a Confucian philosopher from the Edo period, was used to reference the production theory viewpoint of these rituals.

\section{Ritualism of Ogyu Sorai}

In Japan, during the 18th century Edo period, a kind of history called "classical studies" emerged with new methods and problem consciousness in Confucianism. It was first formed as “Kogigaku (古義学)” of Ito Jinsai (伊藤仁斎, 1627-1705); later, “Kobunjigaku (古文辞学)" of Ogyu Sorai appeared in the form of fierce opposition to Jinsai. The concept of "Michi (道)" was emphasized by Jinsai and Sorai. Masao Maruyama, a leading political scientist in Japan, especially recognized the political thinking of Sorai as being comparable to modern Western Europe. Through the thinking of Sorai, Maruyama tried to find a possibility for Japan's own political science to be comparable to that of modern Western Europe. Similarly, this paper points out the emergence of academic languages in Kogaku as comparable to the sociology established in modern Western Europe. Because their discussions can be seen, the fundamental question of sociology, namely, "How is social order possible?" is identified and developed as a question surrounding the concept of "Michi." For example, Sorai said, "The Michi of Confucius is the Michi of the ancient kings.” The ancient kings (先王) and saints (聖人) were producers of the Michi, or social order, and brought them to the man in distant ancient times. This allowed human beings to acquire "culture" and lead a social life as human beings.

Social thinkers in modern Western Europe have answered this question as follows. Humans exist as independent individuals, and they are in an unstable state because their interests conflict with each other. Thus, the way of thinking is that human beings need to form social groups by transferring a part of their rights. After the writings of Thomas Hobbes (1588-1679), social contract theory was based on this way of thinking (Hobbes 1928). This is well known as the "Hobbesian Problem" formulated by Talcott Parsons (1902-1979). This way of thinking explains the transition from the "natural state" before human beings formed social groups to the "social state," in which human beings form social groups. It may be described as a transition from "nature" to "culture." The important point is that the natural state is regarded as a "theoretical 
model" to explain the origin of society. In this way, it is possible to create theoretical and hypothetical stories about the origin of the society according to the flow from the natural state to the social state (Parsons 1968).

Sorai stated the transition of human beings from the natural state to the social state as follows:

In ancient times, when saints could not take their place, people's lives were all different, so there was no integration, and the people knew the existence of mothers but did not know the existence of fathers. Even if their descendants went around everywhere, they did not ask about that. Although they live in the land and enjoy the produce of the land, they do not know their ancestors. The dead are neither buried nor enshrined. People gathered in wildlife to end their lives and disappeared with vegetation. There was no happy life for people. That is because things that people need to follow are not formed in those days. Thus, saints (聖人) enacted a feast of souls of the dead (鬼神) to integrate the people, built places where souls of ancestors were enshrined and held festivals of spring and autumn to honor souls of ancestors (Ogyu 1985).

This presents a vivid picture of the natural state before human beings formed social groups.

Furthermore, Sorai said that when a child is born, it is possible to know the mother who gave birth to the child but not who the father is. It is biologically impossible to identify the father and that the concept of father does not exist, which means there is no marriage. Therefore, as a result, groups such as families and relatives are not formed.

Marriage as an institution is an important condition of whether human beings form social groups. The early social thinkers of modern Western Europe had a keen interest in the origin of the family. Evolutionary ideas have emerged as scientific; the Ancient Society (1877) by Lewis Henry Morgan (1818-1881) is a classic example in anthropology that considers the evolution of the family. Thus, the model of the primitive form of the family suggested by Morgan is promiscuity. This means that there is no distinction between who can marry and who cannot. For now, it is a thing of the past to explain the differences in family types according to evolutionary stages, but Morgan's theory had a great impact at the time.

Sorai's idea of the "natural state" is very similar to Morgan's idea of the primitive form of family. Surprisingly, Sorai presented a similar idea more than a hundred years earlier than Morgan did. Interest in explaining the transition from the natural state to the social state has continued to the marriage theory of Claude Lévi-Strauss (1949).

Sorai thought about how human beings overcame the natural state and transitioned to the social state. What is noteworthy here is that, as he said, "what people need to follow is not formed," and that an "institution" in a broad sense, which is a criterion for enabling human society, needs to be created. Thus, he clearly described the first institution created by saints to transition human beings from the natural state to the social state. In other words, the dead's souls, especially the institution of ancestral ritual, were created. Human beings are integrated into a social group by overcoming the natural state and performing rituals.

Another discussion may be referred to here. It is the discussion that starts from the premise that "human beings are social beings." According to this way of thinking, it is not necessary to assume the natural state before the origin of society. Instead, the 
important question is, "how are human social groups maintained?" There is a way of thinking that says that human social groups are maintained by performing various rituals. Rituals are said to have a "function" of integrating human social groups. It is deeply reflected in sociology after Emile Durkheim (1858-1917).

It can be seen that the view of Sorai is very close to the sociology of Durkheim. Remarkably, he noticed the role of rituals in social formation more than 200 years before Durkheim.

The social thought of Western Europe considers the transition from the natural state to the social state, but it is thought that human beings formed social groups through the creation of rituals or social contract, not by saints. In this regard, the view of Sorai is the way of thinking between Hobbes and Durkheim. It may be said to be a "Durkheim-like solution to the Hobbes problem." The difference is that he considers rituals to be produced by saints. His view indicates that Confucian scholars, like politicians, have gained the perspective of managing and controlling human social groups by creating rituals while placing themselves in the position of saints.

\section{Review of example}

This section connects the ritualism of Durkheim with the production view of the ritualism of Sorai. The logic that creates the sense of recovery among people by designing recovery rituals, planning their situation and timing, and implementing them will be introduced.

In a small fishing village called Kobuchihama, located in Ishinomaki, Miyagi Prefecture, which the Great East Japan Earthquake damaged in 2011, only 18 of the 150 houses remained after the tsunami. In July 2016, we investigated a revival of the summer festival in this area. Many young people were walking in the village carrying monuments of gods, called "Omikoshi" (portable shrines), and shouting slogans. The young people were college students from Tokyo, not the residents who volunteered to help the festival. The residents who lost their homes due to the tsunami were living in temporary houses. Older people from temporary houses gathered while hearing the slogans of the festival.

Interestingly, a local shrine festival is generally open only to shrine members, residents called "Ujiko" (shrine parishioners). Others are only allowed to see the festival, not to participate in it. However, after many people lost their homes, died, and went missing in the disaster, external volunteers were allowed to participate. Usually, the festival is used as a barrier for rejecting outsiders, but it becomes a "mediation" tool for accepting outsiders during a crisis.

Disaster-affected communities have collective traumatic memories. The revival of the festival is a symbolic reenactment of the community before the disaster, symbolically expressing the recovery of the community's spirit.

It is important to note that Sorai's ritualism focuses on the ritual that evokes memories of the dead, acts as if the dead resurrected there, and expresses the exchange between the dead and the living. The recovery ritual also recalls memories of a local community before a disaster destroyed it, acts as if the local community has recovered, and expresses reconciliation and harmony between the past and the present. It is the 
wisdom of the community that heals collective traumatic memories. In that sense, his ritualism and symbolic recovery are also theories of memory management.

Another example is as follows: Hoichi village, located in the mountainous area of Higashimiyoshi town in Tokushima Prefecture, where we have been investigating for over ten years, is a typical depopulated area suffering from population decline and aging. If depopulation can be seen as "another disaster," then depopulated areas can also be perceived as major damaged areas.

There are two notable activities in this village. Since a single road connected the village with flatland, the flatland was isolated every year due to heavy rains and snowfall. For this reason, the president of the residents' association cultivated the land and built a heliport for rescue and emergency medical helicopters to land. Another activity is the revival of the puppet show by repairing the puppet show stage (cultural heritage) that has not been used for more than 80 years. Moreover, a local art festival involving music and traditional dance groups, which are the hobbies of nearby residents, is planned and held.

Departments within a public office in charge of holding art festivals and disaster prevention activities are different, and each academic field dealing with them is also different. However, for residents, both of them are activities that have the same purpose of protecting the village. The superficial purpose of the art festival is to revitalize the depopulated village. However, a hidden purpose of the president of the residents' association is to establish relationships (networks) with performers and tourists coming from outside the village, thereby securing supporters outside the village in case of disaster. It creates a system that accepts outsiders by creating a new festival.

This case is also an example of using the cultural heritage and the festival to recover the local community. The president of the residents' association is a typical "mediated intellectual."

Researchers involved in the recovery support of the disaster-affected community should engage in a series of recovery ritual processes from production to implementation while coordinating and supporting the mediated intellectual within the group. This is because the recovery ritual design is an important and indispensable part of community recovery. Furthermore, the knowledge of designing community recovery is thought to be created by aggregating the knowledge through relations with not only residents and mediated intellectuals but also various outsiders, including researchers. The production view of rituals also leads to the potential for "collaboration" among residents, victims, and researchers.

\section{Sociology of narrative}

\section{Narrative theory of Motoori Norinaga}

The lifelong environmentalism of Hiroyuki Torigoe (鳥越皓之, 1944-), the original Japanese environmental sociologist, was strongly influenced by the perspective that emphasizes the feelings (心意) of the “common people (常民)," which was put forward by Kunio Yanagita (柳田国男, 1875-1962), who was the founder of Japanese native folkloristics along with sociologist Aruga Kizaemon (有賀喜左衛門,1897-1979) (Torigoe 2002).

Moreover, the folklore of Yanagita is influenced by Motoori Norinaga, a Nativism scholar of the Edo period. In particular, Yanagita's theory of mind is influenced by Norinaga's essay on waka (Japanese traditional style poetry) and the theory of "mono no 
aware wo shiru" (translated as "knowing an empathy toward things"), which was developed in the study of "Genji Monogatari" (源氏物語, The Tale of Genji), one of the oldest novels in the world.

Norinaga engaged in the completion of Nativism by applying Sorai's methods of Kogaku to Japanese classics. The important point here is that Sorai, a scholar and politician, noted the sociality of human behavior as an object of governance, while Norinaga, a scholar, focused on the sociality of human words and narrations from the standpoint of the general public.

Based on Norinaga's theory of "knowing an empathy toward things," we have tried to develop a sociology of "narration" and "narrative" (Yama 2017)

Norinaga used wakas to explain the occurrence of emotion in human beings who feel empathy deeply by touching a thing; he explained that human beings feel empathy because the object can recognize their empathy. In this regard, he presented epistemology by integrating "knowing" and "feeling." Furthermore, he talked about the meaning of a waka as the narration and its sociality based on listeners, as if telling a story comforts the mind. On the other hand, narrative theory identifies the meaning of narratives from the reader's perspective compared to the present with the past to relax the mind. Moreover, the writer writes a narrative to communicate empathy to the reader from the perspective of a narrative teller who understands empathy. Norinaga recognized that the narrative writer, character, and reader were integrated into the enjoyment of the narrative in the role of those who understand empathy.

In the following section, we outline Norinaga's essay on waka poetry and narrative theory and then review an example of machizukuri (community development) using a folktale. By comparing the present with the past through the folktale, the residents as enjoyers knew empathy toward things, understand their situations and feelings, and relax their minds.

A sociologist is moved by residents' knowing empathy toward things from their narration and communicating the feeling of empathy that the sociologist felt by describing the residents' narrative (ethnography).

\section{Motoori Norinaga's essay on Waka poetry}

Norinaga developed the theory of "an empathy toward things" in his essay on waka poetry titled “Isonokami no Sasamegoto (石上私淑言)” and the theory of Genji Monogatari “Shibun yoryo (紫文要領).” These works are estimated to have been written around the 13th year of the Horeki era (1763). Additionally, Isonokami no Sasamegoto was not published in Norinaga's life, along with the essay on waka poetry titled "Ashiwakeobune (排蘆小船)," which is supposed to have been written during the second to seventh years of Horeki (宝暦), while Norinaga was studying in Kyoto. After that, he revised the work and completed it as "Genji Monogatari Tama no Ogushi (源氏物語玉の 小櫛)” in the 8th year of the Kansei era (1796) when he was 67 years old. At this time, his theory of empathy was completed (Koyasu 2010).

\section{Essay on Waka poetry "Isonokami no Sasamegoto"}

Norinaga said a poem is written because all creatures have feelings, and feelings make them think and create a poem when they touch an object. In particular, human beings 
cannot stand being without a poem since they have more things to think about than animals. It can be called the emotional origin of the poem, as the occurrence of the poem is derived from human feelings. Since human beings know empathy, they are thoughtful. Because they know empathy, their thoughts can be deepened, so poems are indispensable for them.

\section{Knowing empathy toward things}

Norinaga said that "empathy" does not refer to only sorrow among human feelings; it is a deep feeling from the heart. Moreover, he described it as "feeling from things and sighing" (Motoori 2003).

When explaining why people have feelings of empathy, he stated as follows:

When you look at a flower or the moon, the feelings of empathy move. It is because you feel that you "know from the heart" the empathetic feelings of a flower or the moon. Feelings of empathy arise because such things are known as empathy.

In other words, empathy toward things is based on social and cultural promises, and whether you can understand the promises determines whether you feel empathy. Since such social and cultural promises are known as knowledge and culture, it is possible to know them as empathy; therefore, feelings change. The idea of what can know and that of what can feel are inseparable.

Feelings change by reaching out to not only flowers and the moon but also everything in the world. "Knowing empathy toward things" means that the appropriate feelings are felt according to each thing, such as happy or sad things. Because they experience knowing empathy toward things, people read poems.

Poems are composed when human beings are not able to bear empathy toward things. When empathy is felt deeply, an individual is not satisfied enough to compose a poem for themselves, comforting themselves by telling others. If the listeners feel empathy, then their feelings are very relaxed. In other words, a poem is formed when empathy toward things is communicated with listeners through the poem. This is a discussion by Norinaga that points out the sociality of poems in that it assumes the existence of listeners.

Moreover, according to him, human beings relax their feelings by telling others. $\mathrm{He}$ stated that their feelings are finally relaxed when their listener says "yes" and understands and empathizes with their thoughts. Therefore, telling others is a habit that is difficult to stop. A poem is understood as something like "narration," in which people tell their thoughts. In that sense, his essay on waka poetry could be interpreted as a statement of his own ideas about the narration. Moreover, Norinaga's understanding of narration can be considered the same idea as narrative therapy based on social constructivism.

\section{Norinaga's theory of actual feelings}

Norinaga mentioned the relationship between a poem and actual feelings in his essay on waka poetry, titled "Ashiwakeobune" (Treatise on Waka Poetry), which is about whether a poem is written because the author is unable to bear empathy and needs to reveal their feelings. 
He criticized the utility of poems, which had been explained by an essay on waka poetry (explanations that poems are written to help politics or morals) based on Confucianism and neo-Confucianism at the time. He said that a poem aims to speak what you think from the heart. It should be noted that what he said here is not a principle of actual feelings referred to as actual feelings. Norinaga thought that apart from actual feelings when considering which words to choose and express when writing a poem, one's mind begins wandering and thinking about "creation consciousness" (Sugita 2011), which is also a version of expressing one's actual feelings.

His perception of the times is behind this idea. Once people in the past converted their actual feelings into words, it became a poem; however, now, human feelings and words have changed, so it is thought that the actual feelings that had previously been converted into words could not be a poem. For Norinaga, a poem is an old poem, and he thought that the ideal poem should try to be as close to the old poems as possible, in a classical way. Then, the feelings can also be approached through the feelings of the old poem, i.e., "feelings of the waka-like community (Yamashita 1988)." Therefore, it is impossible to deny that the feelings expressed by trying to compose a poem are not actual feelings just because they are apart from one's actual feelings.

In this regard, Norinaga considered that a poem is assumed to be formed based on the premise of recipients and listeners. It is because it was seen as necessary to choose words that were commonly used in the world of waka-like culture and follow the traditional manner of production in order to better communicate with others.

In other words, feelings are better expressed and communicated through efforts to select words and study expressions. Furthermore, through excellent words, the feelings also go along with those words. Norinaga thought that one's efforts could acquire the words and expressions of the world of waka-like culture. As a result, it is possible to acquire the "feelings to know empathy toward things" as one's own.

By learning old poems, one can write a poem with expressions suitable for the feelings of empathy. Furthermore, it is possible to make the feeling of empathy your own. It is the idea that a person who writes a poem needs to be a person who learns old poems. The essay on waka poetry from the producer of a poem assumes the perspective of an enjoyer in the world of waka-like culture.

Norinaga's way of thinking about the narration is similar to the social constructivist thinking in modern sociology that narrations are created socially. On the other hand, this way of thinking assumes that a true narration is in accord with emotion and that it has been realized by a long-ago waka-like community. This can be said to be an idea of essentialism. Norinaga introduced the "learning theory" of learning old waka poetry to connect those two narration ideas. Considering that the poem party conducts the learning of waka poetry, Norinaga's learning theory presupposes participatory learning. It can also be said that the development from social constructivism to learning theory is ahead of the development of modern sociology. This way of thinking led him to develop his narrative theory.

\section{Narrative theory of Norinaga}

Norinaga developed his original narrative theory in the theory of Genji Monogatari, "Shibun yoryo" (Motoori 2010). Through the essay on waka poetry Isonokami no Sasamegoto and the narrative theory Shibun yoryo, he completed the theory of knowing empathy. 
He attempted to reveal the substance (real intention) of Genji Monogatari in the chapter “Hotaru (蛍の巻) of Genji Monogatari." In the chapter, the protagonist Hikarugenji (光源氏) tells the purpose of the narrative to Tamakazura (玉鬘), who enjoys reading old narratives and is identified as the focus of the narrative theory that Hikarugenji spoke of, instead of the author Murasaki Shikibu (紫式部).

Hikarugenji said that both good and bad things are circumstances of people in the world. Therefore, a narrative is a tool for communicating with future generations; they have recorded various things that they could not just keep in their minds and are not tired of seeing and hearing. From Hikarugenji's speech, Norinaga described the real intention of writing narratives as the same way of identifying "narration" developed in the essay on waka poetry. It is important to note that the real intention of writers' narrative writing is to inform readers of the empathy toward things they have felt.

Nobukuni Koyasu, a researcher of the history of Japanese thought, stated the following:

The narrative writer, the narrative character, and the narrative reader overlap each other in the narrative as they know empathy. From a deep understanding of empathy, the writer writes a narrative of a good person who knows empathy. The reader deeply sympathizes with the narrative of a good person who knows and shares empathy (Koyasu 2010).

Considering that characters in a narrative are described as enjoyers of the narrative, it is assumed that Shikibu Murasaki also enjoyed reading those narratives. In other words, Murasaki wrote the narrative from the perspective of one who enjoys reading old narratives. Furthermore, given that Norinaga himself was a keen reader of Genji Monogatari, it could be understood as the narrative from the perspective of the reader. It can also be seen from Norinaga's description that by reading a narrative, the reader's circumstances overlap with the characters' circumstances, thereby helping them understand their situation, which comforts and relaxes their mind. It clearly explains the meaning of reading a narrative from the perspective of a reader.

It is important to note that he pointed out that a narrative is not simple fiction but instead deeply permeates the life of the reader. He indicated that enjoying a narrative serves as mental support for living and makes real-life meaningful. It is possible because the narrative writer, the narrative character, and the narrative reader are penetrated and overlapped by the feelings of empathy.

\section{Review of example}

Thus far, we have reviewed Norinaga's theory of empathy. In the following, based on that exploration, we will consider a specific example. Based on the discussion of Norinaga's narration and narrative, we would like to reinterpret the example.

Naruto city, Tokushima Prefecture, with the aim of revitalizing local human relations and communities, is making efforts on the machizukuri by resident volunteers using a folktale handed down in the region. The outline of the folktale is that a large monkey who harmed the residents and ruined the crops was eliminated by brothers who hunted it. The story is that the older brother first came to eliminate the monkey and was then killed by the monkey, and his younger brother took revenge for the older brother's death. 
The residents working on the local revitalization have made a plan to cut trees and weeds, maintain mountain roads, and install information boards in several places to increase the number of visitors that come for hiking or walking. They have made the folktale into a picture-card show, a performance at the local elementary schools, and a field trip for elementary school students to picnic at Mt. Ooasa, the setting of the folktale.

On the other hand, damage caused by local monkeys has become serious in recent years. As the interaction between the residents and the mountain has decreased, the residents no longer go to the mountain. Thus, the monkeys have gradually become less afraid of humans. Generally, when we review this transition, we can see that cute monkeys have become hateful monkeys who cause damage, so the local populace wants to eliminate the monkeys. Changes in the relationship between humans and nature are progressing in the form of damage caused by monkeys and the elimination of these monkeys.

In response to this situation, the folktale of eliminating monkeys has been reproduced as a new narrative in the form of a picture-card show. The picture-card show has turned into a new narrative in which residents who have suffered damages from monkeys eliminate the monkeys, thereby regenerating the community. At the same time, the story distinguishes between "good monkey" and "bad monkey," thereby justifying the elimination of the bad monkeys. Moreover, it establishes a new relationship with the good monkeys and reproduces it as a new narrative depicting community regeneration (Yama 2008).

Now, $\mathrm{Y}$ is the one who planned a town revitalization activity based on the folktale of eliminating the monkeys. Hunter $M$ guided the way to the tombs of the monkeys and the hunter, deep in the mountain. $\mathrm{O}$ is the one who turned the folktale into a picturecard show to spread the folktale to the local children. These three are the key members of the activity. Their narrations of what they think of the folktale are shown below.

Y guided people to the tomb of the monkey and said:

Perhaps there was an incident in the village just below this mountain in which a woman or a child was severely injured by a monkey. It may have triggered eliminating the monkey (Yama 2010).

Understandably, the monkey is also desperate to survive because there have been terrible events in history that have triggered the desire to eliminate the monkey. However, a key point of the narration is that it shows the circumstances in which the monkey should be eliminated because it cannot be overlooked. In other words, Y excuses that the monkey is pitiful, but its elimination is inevitable. The narration of Y shows a complex mix of compassion for the monkey and sorrow for killing it. The fact that $\mathrm{Y}$ narrated it in front of the monkey's tomb also indicates that $Y$ experienced these feelings.

$\mathrm{Y}$ has compassion for the killed monkey, the hunter's feelings, and the residents who had to eliminate the monkey. At the same time, the folktale tells the feelings of the residents who are forced to eliminate the monkey due to damages caused by the monkey in their daily lives.

The narration of $\mathrm{Y}$ corresponds to the theory of Norinaga, in which he experiences empathy toward old things through a narrative, knows empathy toward present things compared to the past, and is comforted and relaxed by the mind.

The following is the narration of hunter $M$, who also actually eliminates the monkeys. 
Even if it is a harmful animal, eliminating it must be murder. No one wants to do it. My family also requested that I stop killing because it is not good to continue killing. However, it cannot be left as it is, and if so, someone should do it. When I continued to eliminate the animal with such confusion, it was an opportunity to participate in the machizukuri activities. I regarded myself as the hunter of the folktale who eliminated the monkey and promised myself that I would eliminate the harmful animal (Yama 2010:87).

M compares himself to the hunter of the folktale who understands his situation, comforts his feelings, and makes up his mind. It clearly shows the attitude of the narrative enjoyer, as Norinaga said.

In addition, from the perspective of a narrative enjoyer as the writer, the person who described the narrative is $\mathrm{O}$, the producer of the picture-card show. The picture-card show entitled "Monkey's Tomb and Hunter's Tomb: A Narrative of Love and Courage" added the opening of a scene depicting a peaceful coexistence between residents and monkeys, which was not in the folktale. Moreover, characters such as the woodcutter's son "Daisuke" and the little monkey "Sasuke" were added and restructured around the change in the relationship between Daisuke and Sasuke. The contents are introduced as follows.

Mt. Ooasa was blessed with wealthy nature, and the residents lived peacefully with monkeys and wild boars. Daisuke and Sasuke got close to each other and played with the children of the village every day, but one day, Sasuke suddenly stopped coming. After that day, the monkeys started ruining fields, hurting livestock, and even harming residents, causing severe injuries. The reason was that a specific monkey, a 3-m tall monkey with spiritual power, began to dominate the other monkeys. The monkeys could not go against the large monkey, and "their minds were being ruled." The residents then asked a hunter to eliminate the monkey, thinking that "if the large monkey could be eliminated, peace could be restored." The original story of the picture-card show includes an episode ten years after eliminating the monkey. Daisuke, who became an adult, found that monkeys had put flowers and fruits on the dead hunter's tomb every day for ten years and reunited with Sasuke there. Daisuke regretted that he had not remained close with the monkey Sasuke; he told the residents about this regret, and they then regenerated the interactions between the monkeys and the residents.

O said the reason he was interested in the folktale is that "he felt common feelings in the quite short story." It portrays the "love and courage" that have disappeared in modern times. It exactly fits the word "chivalrous spirit." If someone is in trouble, you cannot ignore it. It is a natural feeling that is not calculative, so it can be taken for granted. Furthermore, regarding the purpose of making the picture-card show, O said, "I tried to express the real intention of the folktale in my own way, which I wanted to convey something to the local children."

$\mathrm{O}$ has restructured and expressed the folktale as a new narrative accepting the real intention of the folktale from the perspective of a narrative enjoyer. The real intention of the folktale is the "feelings to know empathy toward things," as he obtained from the folktale and is describing the new story to convey it better.

We want to summarize the review in the previous section based on the discussions of Norinaga: (1) the narrative handed down to the region is a folktale that corresponds to the "old narrative" in the chapter Hotaru; (2) the current "narrative" of the inhabitants 
living in the region tells of damages inflicted by monkeys, elimination, and machizukuri; (3) from the narrations of the inhabitants surrounding the folktale, it is found that the inhabitant as an enjoyer of the narrative who compared past things to the present felt empathy toward past things, knew empathy toward present things compared to the past, and comforted and relaxed the mind; and (4) the inhabitant, as an enjoyer of the narrative, narrated a new story to convey the feelings to know empathy toward things, thus turning the folktale into a picture-card show. What we can see here in the situation itself is that the narrative writer, the narrative character, and the narrative reader overlap here as a way of knowing empathy. Since the example deals with machizukuri using folktales corresponding to the old narrative, it seems to fit Norinaga's narrative theory relatively well. However, it should be noted here that in this example, I found the inhabitant to be an enjoyer of the narrative who knows empathy toward things. Thus, the sociologist corresponds to the writer of the narrative.

Our mind moves by seeing and hearing activities and narrations of $\mathrm{Y}, \mathrm{M}$, and $\mathrm{O}$; therefore, we think we want to deal with them. Thus, by describing their activities, we want to tell many people about these people. Sociologists and inhabitants move their feelings by seeing and hearing and cannot just keep them in their minds, so they write narratives to tell narrations to others. $\mathrm{Y}, \mathrm{M}$, and $\mathrm{O}$ are described as characters who know empathy in our narrative (ethnography). In other words, in a narrative drawn by a sociologist, an inhabitant who knows empathy toward things is depicted.

Considering this, it is clear that listening to the narrations of inhabitants living in the region is a starting point. According to Norinaga, the narration expresses an inhabitant's feelings, requires a listener, and relaxes a mind.

For sociologists to understand the narrations of people in this sense, it is necessary to face narrations of the world created by people through a field survey with sufficient amounts of time, as Norinaga struggled to acquire the "feelings of waka-like community." Furthermore, an effort is required to understand empathy. This allows sociologists to deeply understand the feelings of local people and open the possibility of "collaboration" with the local people. Norinaga's narration theory can also lead to a research method called action research based on narratives drawing attention in modern sociology.

\section{Conclusion}

In the above, a potential discipline of sociology has been introduced based on the symbolic recovery proposed by us, which connects Western sociology theories with the ritualism of Confucian philosopher Sorai and the narrative theory of Nativism scholar Norinaga. Additionally, many premodern Confucian scholars and Nativism scholars of the Edo period developed thoughts comparable to Western sociology.

Japan rapidly introduced modern Western science in the Meiji period because it already had academic languages comparable to modern Western science; thus, the translation proceeded smoothly. This means that academic ways of thinking that were comparable to modern Western science were developing in Japan. The translation is a creative work. Translating Western academic languages into theoretical academic languages is also a process of creating disciplines with new hybrid ways of thinking. Japanese scholars in the Meiji period worked deliberately to create hybrid studies. Masao Maruyama and Kunio Yanagita were representative scholars of hybrid studies. 
Through this study, we hope to contribute to identifying and reevaluating sociology in the non-Western world by understanding sociology in a broad sense that is not limited to Western sociology, to design sociology that integrates Western sociology and non-Western sociology based on these achievements, and to make use of sociology for solving social problems in a globalizing society.

\section{Acknowledgements}

N/A

\section{Author's contributions}

YY designed the study and conducted research. The author read and approved the final manuscript.

Funding

The author received no specific funding for this work.

\section{Declarations}

Competing interests

The author declares no competing interests.

Received: 19 June 2020 Accepted: 24 February 2021

Published online: 16 March 2021

\section{References}

Anderson, B. 1991. Imagined. Communities: Reflections on the Origin and Spread of Nationalism. New York: Verso.

Cohen, P.A. 1985. The Symbolic Construction of Community. New York: Tavistock Publications.

Douglas, M. 1970. "Natural Symbols: Explorations in Cosmology." Penguin.

Durkheim, E. 1912. Les Formes élémentaires de la vie religieuse: le système totémique en Australie [The Elementary Forms of the Religious Life]. Paris: Alcan.

Geertz, C. 1980. Negara: The Theatre State in Nineteenth-Century Bali. New Jersey: Princeton University Press.

Gennep, A.-v. 1909. Les rites de passage [The Rites of Passage]. Paris: É. Nourry.

Hobbes, T. 1928. Leviathan. J. M. Dent \& Sons Ltd. New York: J.M. Dent \& Sons Ltd.

Koyasu, N. (2010). “「解説」本居宣長『紫文要領』 [(Exposition) Motoori Norinaga "Shibun yoryo"]." 岩波文庫.

Lévi-Strauss, C. 1949. Les Structures élémentaires de la parenté. Paris: Mouton.

Lévi-Strauss, C. 1958. Anthropologie Structurale Deux [Structural Anthropology]. Paris: Plon.

Maruyama, M. (1974=1952). “日本政治思想史研究 [Studies in the Intellectual History of Tokugawa Japan]. ”岩波書店

Motoori, N. (2003). “子安宣邦校注『排蘆小船 石上私淑言』[“Ashiwakeobune and Isonokami no Sasamegoto” Collation Editing by Nobukuni Koyasu]." 岩波文庫

Motoori, N. (2010). "'Shibun yoryo" Collation Editing by Nobukuni Koyasu." 岩波文庫.

Ogyu, S. (1985). “「徂徠集」『近世儒家文集集成』 [Sorai Collection “Early Modern Confucianism Collection"].” ペクかん 社.

Parsons, T. 1968. The Structure of Social Action. New York: Free Press.

Sugita, M. (2011). “宣長の源氏学 [Norinaga's Genji Studies].” 新典社

Torigoe, H. (2002). “柳田民俗学のフィロソフィー [Philosophy of Yanagita folklore]." 東京大学出版会

Turner, V. 1969. The Ritual Process: Structure and Anti-Structure. London: Routledge \& K. Paul.

Yama, Y. (2006). 『象徵的復興』とは何か [What is Symbolic Recovery]. “先端社会研究," pp. 153-175.

Yama, Y. (2008). “民話の環境民俗学一猿退治伝説と猿害問題のあいだ，山泰幸川田牧人古川彰編『環境民俗学』

[Environmental Folkloristics of Folktale: Between the Folklore of Eliminating Monkey and the Problem of Damages

Caused by Monkey, Yoshiyuki Yama, Kawada Makito, Fukukawa Akira, Ed., “Environmental Folkloristics"]." 昭和堂.

Yama, Y. (2010). 民話に学ぶ環境民俗学一人と自然の物語 [Environmental Folkloristics of Folktale: The Narrative of Man and Nature]. "BIO-City," pp. 44:82-87.

Yama, Y. (2017). 物の哀れをしるより外なし-環境民俗学の認識論- [Forced to Know the Empathy of Things: Epistemology of Environmental Folkloristics]. "環境社会学研究," pp. 53-66.

Yama, Y. (2019). “江戸の思想闘争 Thought Struggle of Edo]." 角川書店.

Yama, Y. (2020). 「媒介的知識人」とは何か [What Is an “Intermediate Intellectual"?]. "災害復興研究," pp. 83-91.

Yamashita, H. (1988). “本居宣長と「自然」 [Motoori Norinaga and "Nature"].” 沖積舎.

\section{Publisher's Note}

Springer Nature remains neutral with regard to jurisdictional claims in published maps and institutional affiliations. 